\title{
Ethical Tensions from New Technology: The Case of Agricultural Biotechnology
}

H. S. James Jr.

Debra M. Strauss

Fairfield University, dstrauss@fairfield.edu

Follow this and additional works at: https://digitalcommons.fairfield.edu/business-books

Copyright 2018 CABI Publishing Biotechnology Series

Chapter 6 has been archived here with the permission of the copyright holder.

\section{Recommended Citation}

James, H. S. Jr. and Strauss, Debra M., "Ethical Tensions from New Technology: The Case of Agricultural Biotechnology" (2018). Business Faculty Book Gallery. 40.

https://digitalcommons.fairfield.edu/business-books/40

This item has been accepted for inclusion in DigitalCommons@Fairfield by an authorized administrator of DigitalCommons@Fairfield. It is brought to you by DigitalCommons@Fairfield with permission from the rightsholder(s) and is protected by copyright and/or related rights. You are free to use this item in any way that is permitted by the copyright and related rights legislation that applies to your use. For other uses, you need to obtain permission from the rights-holder(s) directly, unless additional rights are indicated by a Creative Commons license in the record and/or on the work itself. For more information, please contact digitalcommons@fairfield.edu. 


\title{
(2) Genetically Modified Organisms in Food: Ethical Tensions and the Labeling Initiative
}

\author{
Debra M. Strauss* \\ Charles F. Dolan School of Business, Fairfield University, Fairfield, \\ Connecticut, USA
}

\section{Introduction}

This chapter explores the ethical implications of genetically modified organisms (GMOs) in food that originate from plants genetically altered through bioengineering. The tensions between the proliferation of agricultural biotechnology and consumer concerns about potential harm to human health and the environment ultimately cause us to reflect on the current regulatory scheme in the USA. Does the failure to require adequate, meaningful labeling, and the preemption of grassroots efforts to do so, violate our right to informed consent by not allowing consumers a choice as to whether to knowingly and willingly assume the risks of ingesting GMOs?

Genetically modified (GM) plants involve a uniquely invasive application of agricultural biotechnology, unlike traditional plant breeding and hybrid methods used in the past. Through this novel process, the DNA of one organism is inserted into another, causing the target trait to be expressed in that non-related species at the cellular level throughout the plant, including the fruit or vegetable and the component ingredients that become part of a variety of food products. Most commonly, GM plants are engineered to withstand a weed-killing pesticide, Roundup, sold by Monsanto along with the herbicide-resistant varieties of soybeans, canola, cotton, corn, radicchio, rice and sugar beet. In addition, genes derived from a bacterium in the soil used as an insecticide, Bacillus thuringiensis $(\mathrm{Bt})$, have been inserted into crops to induce the plant to produce a toxin against certain insects, producing Btcorn, Bt-cotton, Bt-potatoes, Bt-rice and Bt-tomatoes (Strauss, 2006).

There is even a biotechnology invention, as yet undeveloped for commercial use due to widespread consumer opposition in the international community, called the 'Terminator' gene, also known as Genetic Use Restriction Technologies (GURTs). Developed jointly by the agricultural biotechnology industry and the United States Department of Agriculture (USDA), this technology genetically alters plants to produce sterile seeds at harvest, effectively blocking the ability of the plant to procreate future generations in order to prevent farmers' traditional practice of saving and replanting harvested seed and thereby necessitating the purchase of new seeds from the biotechnology company each year (Strauss, 2009). Recognizing the conceivable catastrophic effect on the global food supply if spread via common cross-pollination, the United Nations, through the UN Convention on Biological Diversity in 2000, implemented and has continued to maintain a de facto moratorium on these sterile seed technologies (Convention on Biological Diversity, 2017). Ultimately, 
the very existence of the Terminator serves as a reminder that there is virtually no limit as to what might be developed in the future through this novel technology.

In the USA, GM crops now comprise almost all of the plantings and the vast majority of component products in the US market (Strauss, 2012a). Recent statistics indicate that GM crops accounted for $94 \%$ of soybeans, $92 \%$ of corn and $96 \%$ of cotton planted in 2017; and GM canola, squash, papaya, alfalfa and sugar beet were widely planted (USDA, 2017a). The Grocery Manufacturers Association (GMA) reported in 2005 that $75 \%$ of all processed foods in the USA contained a GM ingredient, including almost every product with a corn or soy ingredient and some with canola or cottonseed oil; this figure has continued to be widely cited. However, projecting from the exponentially higher plantings since then, the prevalence should be substantially higher today. The current GMA position statement emphasizes the proliferation of GMOs:

It is important for our consumers to know that this technology is not new. In fact, it has been around for the past 20 years, and today, $70-80 \%$ of the foods we eat in the United States, both at home and away from home, contain ingredients that have been genetically modified. If the ingredient label on any food or beverage product contains corn or soy, they most likely contain genetically modified ingredients, as a very high percentage of those crops grown in the U.S. use GM technology. In addition, a high percentage of other ingredients in the U.S., such as sugar beets, are grown with the use of GM technology as well. (2017, n.p.)

Yet the widespread use of GMOs is unknown to most consumers because, unlike the European Union and the broader international community where more than 60 countries require labeling, the USA does not dictate mandatory labeling, rigorous approval or monitoring of GM plants and foods (Strauss, 2006; Consumer Reports, 2014). Moreover, due to the absence of long-term studies, the level of safety and the effect on human health and the environment remain uncertain.
Surveys on GM foods reveal that a significant majority of consumers believe that the government should include ethical and moral considerations when making regulatory decisions about genetic engineering. Moreover, consumers seek an active role from regulators to ensure that new products are safe (Strauss, 2007). Consumer polls uniformly demonstrate that a vast majority of US citizens would like GMOs to be labeled (Center for Food Safety, 2017). For instance, a recent Consumer Reports National Research Center survey found that $92 \%$ of Americans prefer GM foods to be labeled and more than $70 \%$ indicated that they do not want GMOs in their food (Consumer Reports, 2014). This is a critical area where examining the ethical implications can lead to further developments in the law as a means for the community to address and resolve these issues.

The juxtaposition between the proliferation of agricultural biotechnology and consumer concerns will be explored in view of the critical role of food safety in human health and the environment. To this end, the next section examines the key ethical issues arising from genetic engineering, particularly the right to informed consent and conflicts of interest in studies and scientific research that may hamper inquiry into the possible long-term risks. The chapter then analyzes the new federal statute recently passed in the USA purportedly to label these foods and evaluates whether in fact it does so in an effective and meaningful way to fulfill these consumers' rights. The chapter highlights an approach that takes into account these ethical tensions and shifts the dialogue from public outcry to the policy and regulation arena. Accordingly, this proposal embraces participation of all stakeholders, education of the public on the potential risks, development of comprehensive labeling to enable informed consumer choice and establishment of a more active and independent role for government agencies in regulating biotechnology companies. The chapter concludes by providing queries to assist policy makers in implementing a new regulatory framework in the USA, recognizing that consideration be given to ethical tensions in shaping the international policy arena. 


\section{Ethical Tensions in Connection with GMOs}

To recognize an ethical perspective in the ongoing discussions about GMOs, the Food and Agriculture Organization of the United Nations (FAO) formed an expert panel on ethics in food and agriculture, which met in four sessions and issued reports on specific focus areas (FAO, 2007a). The first report of the FAO panel, 'Ethical issues in food and agriculture', introduced ethical questions related to its mandate, such as: What is the value of food? What is the value of human health? What is the value of nature and natural resources? The FAO panel recognized as principles the right to adequate food, optimization, trust, equity and informed consent in identifying these ethical concerns as central to the debate about the future (FAO, 2001a).

The FAO's second report, 'Genetically modified organisms, consumers, food safety and the environment', stressed the role of ethical considerations in food and agriculture with regard to GMOs as well as food safety and the environment (FAO, 2001b). Issues examined included ownership of the necessary tools to produce GMOs, potential consequences of their use and undesirable effects that could result from their application, both now and in the future. Most important, the report advocated the participation of all stakeholders in making decisions regarding GMOs, emphasizing that '[w]idely communicated, accurate and objective assessments of the benefits and risks associated with the use of genetic technologies should involve all stakeholders ... Experts have the ethical obligation to be proactive and to communicate in terms that can be understood by the lay person' (2001b, p. 25).

The FAO's third report delved further into the risks of GMOs and the ethical imperative to make human health and the environment the paramount concern and accordingly restrict the use of this technology:

Genetic engineering introduces a new uncertainty, as it affects the genetic design of plants and animals and thus the composition of our food. The Panel reiterated the concern expressed in its earlier sessions over the potential environmental, health and socio-economic impacts of genetic engineering and genetically modified organisms (GMOs). Unless there is an overriding advantage that is apparent, the Precautionary Principle, which is the foundation of the Cartagena Protocol on Biosafety, would point to a preference for non-genetically engineered food. Even when there is an obvious advantage, an exhaustive testing of the safety of the genetically engineered food is required. (2005, p. 4)

In its fourth and final report, the FAO continued to emphasize

the ethical requirement to avoid the risks of, while sharing the benefits of, biotechnologies as part of the advancement of science, which also involves an examination of the ethical issues related to intellectual property rights ... Ethical considerations of decision-making in relation to genetically modified organisms from the perspective of the consumer, food safety and the environment are closely related to this issue. (2007b, p. 10)

Thus, a discussion of ethical tensions is warranted in the public arena, and all of the stakeholders should have a voice in determining the policy decisions that consequently ensue.

These considerations have induced the European Union and other countries in accordance with the precautionary principle to limit the use of bioengineered foods and require labeling of foods with GM ingredients. The continued development of genetically modified plants raises several moral principles, such as respect for nature and the value of life; consideration of the environment; and equity, power and the economically disadvantaged (Strauss, 2007). The most significant ethical tensions will be explored further below: the right to informed consent and the latent impact of conflicts of interest in scientific research.

\section{The right to informed consent}

The foregoing reluctance of the US government to establish a rigorous labeling scheme 
for the treatment of GM crops and GMOs in food raises critical ethical tensions. For consumers, the lack of clear and meaningful disclosure of the fact that their food was developed using bioengineering techniques violates the right of informed consent. From an ethical perspective, particularly a Kantian model, US citizens have been deprived of their autonomy and freedom of choice (Strauss, 2007). Individuals have the fundamental right to know what they are buying and eating before making a purchasing decision.

An economic model also supports transparency and disclosure of this information (Brussel, 2003). According to this reasoning, 'the market for GMOs at both the consumer and producer level is unable to achieve a rational, efficient and socially optimal result due to asymmetrical information' (p. 430). Without adequate information, consumers cannot make rational decisions about whether to purchase and consume GMOs, farmers do not have the tools to negotiate with biotech seed producers and organic farmers cannot effectively allocate resources to protect their crops from contamination by genetic drift. This market can only function efficiently

if a mechanism is established for ensuring that rational, scientifically-based information on the effects of GMOs on human health, agricultural production, and the environment is available to the public. Because transaction costs would be prohibitively high for individual consumers or farmers to obtain such information, a system of mandatory disclosures tied to discretionary participation in the market for GMOs should be established by the government. (Brussel, p. 432)

The government has a responsibility to protect its citizens, particularly in such a critical area as the safety of the food supply. As a matter of ethics, the as yet unknown risks must not be placed on the unsuspecting public rather than on the companies who have created these genetic modifications. To do so would betray consumers' trust in their government to ensure their health and well-being as fiduciaries acting on their behalf. The Food and Drug Administration (FDA) has recognized this mandate in its regulatory approach to other areas of the food supply, for example, applying a zero-risk policy to prohibit the introduction into the food supply of food and color additives determined to cause cancer in laboratory animals (Strauss, 1987).

Moreover, in an area where the FDA perceives there to be no safety risk - food treated with ionizing radiation - it has nonetheless required mandatory labeling of such foods, with the international (Radura) symbol for radiation along with the statement 'Treated with radiation' or 'Treated by irradiation' on the food label (FDA, 2016). In mandating a disclosure on all irradiated foods, the FDA was cognizant of widespread consumer concerns about food irradiation. According to the agency, 'the large number of consumer comments requesting retail labeling attest to the significance placed on such information by consumers' (Strauss, 2006, p. 184; United States, 2012). Yet the FDA has not applied this reasoning for GMOs in food, where only nonbinding recommendations for voluntary labeling have been its policy (FDA, 2015).

Consumers have the right to choose what they eat, and informed choice can only be realized through mandatory labeling on the package that is accessible and understandable. According to Consumers International, consumers' desires and opinions should be respected due to a fundamental right to know and make informed decisions (Halloran and Hansen, 1999). For example, a lack of labeling as to the presence of an introduced gene removes the individual's right to avoid known allergens and control their own fate. Eight percent of children in the USA have food allergies, some of which can be fatal (Kolehmainen, 2001). When Pioneer HiBred spliced Brazil nut genes into a soybean to improve its protein content, the altered soybean provoked severe allergic attacks in eight individuals sensitive to Brazil nuts but not soybeans (Nordlee et al., 1996). Without a label alerting consumers that a soybean could contain genes from a highly allergic nut, even individuals aware of their severe allergies would have no warning. As a matter of policy, vital information about the transgenic processing must be made available to those individuals who could be affected by important health risks (Nestle, 1996). 
While the potential risks generate a need for labeling of the presence of GMOs, such an approach is also required beyond safety issues, as a matter of taste and preference and for many health-related reasons. It must be recognized that many consumers make food choices based on religious, ethical and environmental considerations, for example, deciding not to eat veal, mass-produced chickens or non-organic produce. If biotechnology raises similar ethical, health and environmental concerns, it is not irrational for people to act on these preferences and aversions to risk (Teitel and Wilson, 1999). In order to make these informed decisions, food products must be effectively labeled. As a matter of ethics and public policy, '[s]ince labeling laws are created to meet consumer needs, consumer opinion should be respected' (Halloran and Hansen, 1999, n.p.).

The decision to allow the public to consume unlabeled genetically engineered (GE) food strikes some people as 'grossly undemocratic and slanted too far in favor of corporate interests'. 'Should our society allow the purported commercial rights of a corporation to supersede the citizen's right to make informed decisions in the marketplace?' (Teitel and Wilson, p. 61). 'Every person has a right to make choices about what they eat. Every person has a right to know' (Strauss, 2007, p. 28). With an increasing crescendo of proponents, this concept has been building momentum as a 'Consumer Right to Know' policy grounded on a number of concerns apart from health and safety, including religious, ethical, dietary restrictions and environmental objections (Keane, 2006; Nauheim, 2009; Begley, 2017).

A recent study by the National Academies of Sciences (NAS, 2016) provided support for labeling of GMOs, not based on safety concerns but expressly on the ethical grounds of the consumers' right to know policies that respect consumer autonomy and fairness, reasoning that: if non-GE labeling is voluntary, many products would have no label information about GE content. Consumers would not know whether the product contained GE ingredients and so would be deprived of the ability to make an informed choice about each product' (2016, pp. 305-306). In its most significant statement, the NAS committee concluded:
Mandatory labeling provides the opportunity for consumers to make their own personal risk-benefit decisions (regardless of the regulatory determination of safety) and to express a preference for a method of production. A voluntary non-GE label places the burden on consumers who want to avoid GE foods to search for non-GE products and provides no information to consumers who may not be actively searching for the information but who might be informed by the label. Voluntary labeling also may not help consumers who cannot afford the kinds of foods that will be voluntarily labeled. (2016, p. 306)

For consumers who are careful about the content of the food they eat, choosing organic foods may be an option, but it is not an equitable and practical solution for the majority of Americans. Organic foods tend to be more expensive than non-organic products and they are not available for all types of food, stores and areas of the country. Thus, most consumers do not have the genuine choice and access to purchase organic foods as an alternative to what has previously been known as 'traditional' foods (Strauss, 2007). Moreover, issues of cross-contamination increasingly threaten the integrity and economic viability of the organic food supply (WHO, 2005).

The government has the ethical obligation to protect the safety of the mainstream food supply for all of its citizens. The FAO expert panel on ethics recognized that:

[t]he right to adequate food, as understood today, carries with it obligations on the part of states to protect individuals' autonomy and capacity to participate in public decisionmaking fora, especially when other participants are more powerful, assertive or aggressive. These obligations can include the provision of public resources to ensure that those fora take place in a spirit of fairness and justice. (2001b, p. 25)

The FAO second report concluded that this right has not been fulfilled in connection with genetically engineered products. The most important stakeholders have been excluded from the process because:

[c]itizens have a direct interest in technological developments, yet there are 
obstacles to their participation in decision-making that must be acknowledged and overcome. The public has not been adequately informed about the application of gene technology to food production or the consequent potential impacts on consumers' health and the environment. (2001b, p. 25)

As a result, with the confusing and conflicting jumble of claims in the media, 'the public is losing faith in scientists and government' (p. 25).

Following similar reasoning, Geoffrey Podger, as Executive Director of the European Food Safety Authority (EFSA), promoted a labeling approach as a means to regain the support of the public. He explained that the European opposition to GMOs was based on ethical grounds as a reaction to being denied a choice when GMO and non-GMO varieties could not be differentiated. Thus, the European regulatory approach arose in part as a solution to this ethical and practical duty to inform. The advantage of labeling is that it provides a choice "[a]nd while the people who insist on choice may be quite a small part of the population, they are very vociferous and they are often in positions of power and prominence' (Podger, 2004, n.p.). Accordingly, the key to public perceptions is a transparent regulatory process that gives people readily available information on the science.

The responsibility of government to protect its citizens and respond to their concerns should necessitate, at the very least, mandatory labeling and monitoring of GMOs in food. Past studies have found that, unlike the Europeans, American consumers have generally trusted their government and regulatory agencies. Attitudes toward the government link closely with public perceptions of biotechnology, press coverage and policy formation (Gaskell et al., 1999). This fact offers an even greater reason why it is critical that the government does not betray that trust in an area as fundamental and critical as food safety.

Most recently in the USA, public outrage at being denied a choice has generated a grassroots political effort to raise consciousness of consumers and alert them as to what they are not being told, while advocating labeling (Justlabelit, no date). At the local, state and even federal levels, legislative efforts have attempted to respond to the public's right to know, as well as the safety concerns for consumers and farmers. But a review, below, of the history and current status of those initiatives reveals that these noble goals have not yet been satisfactorily achieved.

\section{Conflicts of interest in studies and scientific research}

Several sources have raised the issue of the close connection between the academic community involved in research and the industries or patents they seek to develop (Hoffman and Sung, 2005). This direct financial stake, via stock options or patent participation, creates an inherent conflict of interest. One fear is that 'the lure of profit could color scientific integrity, promoting researchers to withhold information about potentially dangerous side-effects' (Batalion, 2009, n.p.). As a result of this conflict of interest and disincentives for long-term studies, the actual risks of this novel technology remain largely unknown.

Well-funded programs in plant genetics and genetic engineering are supplanting research to enhance organic methods and other low-input alternatives. A 1990 study discovered that 'from [ten percent] up to one third of biomedical researchers at prestigious universities such as Stanford and MIT had direct corporate ties' (Tokar, 1999, n.p.). With the exponential growth of the biotechnology industry since then, today's figures are no doubt even higher. These ties continue to shift more public funds into projects that support the research agenda of the biotechnology industry.

Some groups have also expressed concern that intellectual property incentives limit the development of more beneficial genetically engineered crops. In July 2003, a coalition of public-sector research institutions announced the formation of the PublicSector Intellectual Property Resource for Agriculture (PIPRA) (Atkinson et al., 2003; PIPRA, no date). Funded by the Rockefeller and McKnight Foundations, PIPRA contends 
that 'the benefits of much publicly funded research come to private industry through university technology transfer programs, limiting universities' flexibility to conduct research' (Hoffman and Sung, 2005, p. 15). As a result, biotechnology patents may not be utilized for developments with little commercial value that would help the poor and promote the original goal of food security.

Because the research at public institutions is often heavily influenced by the source of funding, this predominantly private backing has diverted research time and money away from projects that would benefit the public good, such as biological control, organic production systems and general agroecological techniques' (Altieri and Rosset, 1999, n.p.). This situation has sparked suggestions that '[c]ivil society must request more research on alternatives to biotechnology by universities and other public organizations' (1999, n.p.).

Moreover, one of the significant problems associated with the privatization of biotechnology rights is the company's restriction of information.

While the basic realities of modern business clearly underscore the need for confidentiality, it is also true that confidentiality provisions are often used as a means of avoiding disclosures. In the face of increasing recognition that activities, including especially species introduction, in one country may have serious impacts on neighbouring countries, labelling and other access to information is increasingly addressed at international and regional levels. (Prakash et al., 2011, p. 7)

Sharing of some of this information is crucial for risk assessment, long-term studies and developing buffer zones between genetically engineered and conventional or organic crops that would avoid spreading these risks exponentially through cross-contamination.

In its recent report, the NAS acknowledged that any new food 'may have some subtle favorable or adverse health effects that are not detected even with careful scrutiny and that health effects can develop over time' (2016, p. 19). It recommended additional public funding for research, particularly in cases where early published studies produce 'equivocal results' regarding health effects of a GE crop, 'using trusted research protocols, personnel, and publication outlets to decrease uncertainty and increase the legitimacy of regulatory decisions' (p. 19).

According to one examination of the risks and precautions arising from GMOs:
Regulation of GMO deals with a
transscientific problem, that is, the resolution of the problems is beyond the competence of the scientific system. Public perception and acceptance are dependent on trust and whether the products or processes benefit them as citizens and consumers. To take proper accounts of uncertainties and public concern would help to capture the benefits, minimize the risk, and provide goals for future development and use of genetic engineering. (Prakash et al., 2011, p. 11)

Critical to maintaining the public trust will be embracing transparency and disclosure through a comprehensive and effective labeling policy.

\section{The New DARK Act and Preemption of State Initiatives}

In the shadow of these ethical tensions emerged a new piece of federal legislation that extinguished grassroots efforts to require mandatory labeling of GMOs in the USA. Attempts to regulate the safety and labeling of GMOs had been raised unsuccessfully every year at the federal level through bills introduced in Congress that died a quiet death in committees. For example, in May 2002, H.R. 4814 was one of five bills introduced by Representative Dennis Kucinich (Democrat-Ohio) that sought to expand the regulation of agricultural biotechnology. On 2 May 2006, Representative Kucinich introduced the 'Genetically Engineered Food Safety Act' (H.R. 5268, 109th Congress 2006) and four other bills regarding GMOs (Strauss, 2007). Representative Kucinich introduced similar bills in the 111th Congress, 
including legislation that would have protected farmers and shifted liability to the biotech companies (H.R. 5577, 111th Congress 2010) (Strauss, 2012b). One of the most recent efforts, introduced into the US Senate on 2 March 2016 by Democratic Senators Jeff Merkley, Patrick Leahy, Jon Testor and Dianne Feinstein, the 'Biotechnology Food Labeling Uniformity Act' (S. 2621, 114th Congress 2015), would have informed consumers of the presence of GM ingredients in their food while giving several options to food manufacturers for how to indicate this information on the Nutrition Fact Panel (Merkley, 2016). But this proposed legislation was superseded by the one federal bill that did ultimately become law, discussed below.

At the state level, momentum for labeling appeared to build with the passage of several statewide labeling initiatives, which many hoped would take hold and lead to a stringent mandatory labeling under federal law that would follow the states. In 2013, Connecticut became the first state to pass legislation for labeling GMOs in foods, requiring that the retail packaging contain the clear and conspicuous words 'Produced with Genetic Engineering' and redefining the FDA's use of the term 'natural food' to include food that has not been genetically engineered. However, the Connecticut statute provided that the law would not take effect until the passage of similar legislation by four additional Northeast states, with a total aggregate population of more than 20 million, one of which borders Connecticut (Connecticut General Statutes, 2013). Soon after, Maine passed a similar law requiring genetically engineered food and seed stock to be conspicuously labeled as 'Produced with Genetic Engineering' and prohibiting such foods from being labeled as 'natural'. But the Maine statute also contained a 'trigger' clause providing that at least five contiguous states must pass comparable laws (Maine Legislature, 2013). Numerous other states had launched their own labeling bills, some of which were defeated (e.g. California) but were slated to be reintroduced by advocates (Center for Food Safety, no date).

The most successful and definitive of these state laws was passed in Vermont (Vermont
General Assembly, 2014) in May 2014, with an accompanying rule, 'Consumer Protection Rule 121', which like the previous states required that food entirely or partially produced with genetic engineering be labeled as such. The law applied to raw agricultural products such as corn and squash as well as processed foods like crackers, soda and cereals. Its comprehensive scheme applied to producers, processors, distributors and retailers. Exemptions included processed foods that would otherwise have been subject to the labeling requirement due to containing one or more materials that have been produced with genetic engineering, in which the genetically engineered materials in the aggregate do not account for more than $0.9 \%$ of the total weight of the processed food. The Vermont law was set to go into effect on 1 July 2016, when the biotechnology industry intervened and succeeded in pushing Congress to cut short the state initiatives.

The National Bioengineered Food Disclosure Standard (United States, 2016), pejoratively called the DARK ('Denying Americans the Right to Know') Act like a previous version that had been defeated, was signed into law by President Obama on 29 July 2016. It amended the Agricultural Marketing Act of 1946 to require the Secretary of Agriculture to 'establish a national mandatory bioengineered food disclosure standard with respect to any bioengineered food and any food that may be bioengineered' (Section 293). In a blow to community activists and consumer groups, this statute pre-empted the states from passing their own - and Vermont from implementing its enacted - GMO labeling laws. Furthermore, the USDA sent preemption letters to the governor of every state (USDA, no date(a)). If challenged in court, however, this may be held to be an improper use of preemption, as the federal law currently does not present the requisite characteristics of a comprehensive regulatory scheme. While technically a law requiring labeling, it appears on its face to be so minimal and likely ineffective in its conveyance of information to the consumer that it may be determined to lack adequate and meaningful labeling and thus violate the right of informed consent and effective choice. 
With respect to food, the federal statute defines the term 'bioengineering' as a food 'that contains genetic material that has been modified through in vitro recombinant deoxyribonucleic acid (DNA) techniques ... for which the modification could not otherwise be obtained through conventional breeding or found in nature' and limits its scope to foods that are already subject to labeling requirements under the Federal Food, Drug, and Cosmetic Act, the Federal Meat Inspection Act, the Poultry Products Inspection Act and the Egg Products Inspection Act, as well as the predominance of its ingredients (Sections 291 and 292). Although labeling for these substances in food will be mandatory, it gives manufacturers a choice of the disclosure on the package via 'text, symbol, or electronic or digital link' (e.g. QR code accessed with a smartphone) (Section 293(b) (2)(D)). Small food manufacturers can choose to comply instead by placing a telephone number accompanied by appropriate language to indicate that the phone number provides access to additional information and an internet website with disclosure of bioengineering ingredients; the telephone number disclosure must only state, 'Call for more food information' (Sections 293(b)(2) (F)(ii) and 293(d)(1)(B)).

Critics of this new law note that it does not specifically mandate that manufacturers have to post a label or warning that the food contains GMOs. Consumer groups have expressed concern that manufacturers will choose the method that gives the least amount of information or makes it difficult for consumers to ascertain this information in a timely and effective way in order to be able to make a choice before their purchasing decision (Nat, 2016; Begley, 2017). This problem will be exacerbated by technological limitations if the consumer does not have cell service, a phone capable of reading a QR code, or the comfort level and knowledge to do so (Justlabelit, no date; Center for Food Safety, 2017). A national survey confirmed that $88 \%$ of American voters prefer GMO labeling printed on the package over bar codes that would be scanned by a smartphone app (Melman Group, 2015). In addition, consumer advocates object to the narrow definition of 'bioengineered' and scope of the labeling advocated by the industry, urging instead that 'all foods produced through genetic engineering are labeled; including those derived from genetically engineered sources, such as highly refined sugars and oils and processed corn and soy ingredients' (McCann, 2017, n.p.). Moreover, any threshold set by the USDA should be consistent with international standards - the mandatory disclosure of $0.9 \%$ by individual GE ingredient (2017, n.p.).

Unlike previous statutes that put food labeling in the purview of the FDA, the law designated the Agricultural Marketing Service (AMS) of the USDA as the agency responsible for promulgating additional regulation that would fill in the details to establish a 'national mandatory system for disclosing the presence of bioengineered material' (USDA, no date(a)). The USDA has formed a working group to develop a timeline for rulemaking and posted questions on its website in the summer of 2017 to seek input on a series of issues left open by the legislation to aid in its drafting of the rules. These questions include the scope, threshold levels and definitions of a 'bioengineered food'; the type of text, symbol or digital/electronic link that should be designated 'if a manufacturer chooses to use' it; alternatives for 'very small or small packages'; and definitions for the stated exclusions, such as 'small' and 'very small manufacturers', 'restaurants and similar retail food establishments' (USDA, no date(b)). AMS received over 112,000 responses from individuals and organizations to be used in its drafting of the proposed rule, issued with an additional public comment period.

The USDA also commissioned a study 'to identify potential technological challenges that may impact whether consumers would have access to the bioengineering disclosure through electronic or digital disclosure methods' and published the results on 7 September 2017 (USDA, 2017b). Among its most significant findings was the fact that $85 \%$ of consumers experienced technical challenges when using mobile apps for scanning digital links: 'In addition, most apps contain advertisements that confuse consumers and run 
counter to how the Law requires disclosure when regulations are finalized and implemented' (2017b, p. 4). Pursuant to the law, the USDA is required to have the final rules in place by 29 July 2018, two years after the passage of the legislation.

In view of prospective future court challenges, it would be prudent for the USDA to take the opportunity to strengthen labeling requirements to a level akin to Vermont and other state initiatives or international standards. The Vermont Attorney General's Office has already announced its intention to 'take an active role as the labeling fight shifts from the legislative process in Congress to the regulatory process at the USDA ... We will work hard to give consumers the same access to information, in plain English, that they had under Vermont's law' (2016, n.p.). Pressure will be wielded by consumers, antiGMO groups and other stakeholders to determine if this will be only the first step in a comprehensive and effective mandatory federal labeling scheme or a temporary defeat for states that will ultimately prevail over federal obstructionism. One way or another, the US government must respond to the increasing crescendo of the public outcry for transparency and disclosure in the debate over food safety. Hopefully these governmental agencies will be guided by their charge and uphold their duty to the public to take into account consumer concerns regarding labeling and to make paramount the safety of the food supply for the average American consumer.

\section{A Framework that Addresses these Ethical Tensions}

In light of ethical concerns and individuals' comfort levels in assessing whether the risks are acceptable, American consumers should not be bound to accept the possible consequences of GM foods without their knowledge and consent. With scientific uncertainty about the risks of consuming GM foods unlikely to be resolved in the near future, ethical concerns should be the paramount factor in determining a model of labeling, segregating and monitoring for GM foods.
Reflecting on the ethical tensions that biotechnology creates prompts one to consider questions that should be raised and utilized to construct a more appropriate regulatory response. The current regulatory framework is inadequate because it predates the advent of this technology and forces regulators to conform substances created through a novel process into preexisting and longstanding notions of safety and efficacy. Better public policy would result from approaching this area from an alternative perspective. Under what conditions do consumers have a right to know the process by which their food has been produced? The US already requires labeling to inform consumers about some food production cases (e.g. irradiation). Given the uniqueness of biotechnology and its potential for harm, should this change the way we think about the right to know and implore us to answer this question in the affirmative?

The way of approaching market approvals and labeling requirements in the past has been to focus only on the composition and safety of the product itself without considering the potential risk inherent in the technology. Biotechnology is so fundamentally different that it forces us to rethink that approach. Biotechnology raises issues separate from whether to label the product as to the presence of a particular ingredient or lack thereof, which has been the traditional approach of the FDA. Genetic engineering of food also goes beyond the existing criteria for labeling of the potential for harm embodied by the concept of 'substantial equivalence', regardless of whether the product itself is or is not different. Under the current FDA policy, if a genetically engineered product does not appear to be substantially different than its conventional counterpart, no special labeling or animal testing is required. 'From FDA's perspective, biotechnologicallyproduced products are seen as substantially equivalent to conventional food products because, in the agency's view, there is no scientific basis to presuppose that biotech foods are more risky or substantially different from other food products' (Strauss, 2006, p. 183). However, there is no definition provided in the regulations for substantial 
equivalence or clear guidelines stipulating what to examine and how similar the items in question should be; this concept has been discredited in Europe as unscientific and not adequate to justify a lack of safety assessments (Strauss, 2006). Biotechnology is so extraordinary that there are many unknowns and scientific uncertainty, with potential risks inherent in the technology itself. This innovation calls for a new way of thinking because it would be inappropriate for regulators to impose an existing framework on it. Policy makers should recognize this matter as unique due to the unknowns and possible risks.

The issue of risk is made even more compelling due to the fact that science has not yet advanced to measure and assess these risks using standard risk assessment techniques. Thus policy makers cannot turn to science alone to provide the answers to the pressing questions. A more precautious policy could create the proper incentives for the development of more advanced risk assessment procedures, as well as improved detection methods and long-term studies of safety. Moreover, a more prudent policy with greater emphasis on public safety concerns would be consistent with the government's recent proactive approach towards food safety embodied in the Food Safety Modernization Act (Strauss, 2011). Until such time as these risks can be ascertained with a higher degree of certainty, consumers of these products should be given a choice and allowed to weigh their own personal comfort levels in their purchase and consumption decisions. In view of this scientific uncertainty, effective labeling should be an important component of the revised regulatory framework, along with an education campaign as to the meaning and significance of these GE designations.

This discussion relates to a more fundamental question: when a new technology is introduced, when do people have the right to be informed and what do they have a right to be informed about (e.g. that the product was made through this method)? This concern goes beyond a focus on the potential for harm. As the Terminator gene illustrates, there is no limit to what might be developed through genetic engineering because biotechnology is so profoundly different from traditional crop and animal breeding practices. As a consequence, society needs to develop a different way of looking at it - at the very least labeling and educating the public and ultimately introducing a new regulatory scheme so that as the science and technology develops, new inventions will be incorporated into that scheme. For example, requiring better detection methods and risk assessment for the approval process would both provide incentives to develop that new technology and guide the future direction of the science.

A consideration of these issues highlights the fact that ethical principles must shape the solution for the treatment of biotechnology food products. The incorporation of ethics into policy development should involve all stakeholders: farmers, consumers, the environment, underprivileged populations and the agricultural biotechnology industry. Recognition of the inherent conflicts of interest also necessitates a more active and independent role of regulatory agencies in relation to the biotechnology companies. An important part of this framework would be clear and comprehensive labeling, which is essential for informed consumer choice, as well as a sharing of information and education on the science, including all potential and discovered risks to human health and the environment.

A group of scientific experts identified three important components for risk management: impact assessment, public awareness/ participation and the design of regulatory systems. Above all is involvement of the public: 'It is not possible to overstate the importance of the public's contribution to effective decision making, as well as the importance of public awareness, within the context of government decisions on matters and activities affecting the environment' (Prakash et al., 2011, p. 6). Under this analysis, disclosure and transparency should extend beyond public access to governmental documents and processes:

[T] here are other mechanisms by which public awareness and access to information can be encouraged, including product 
labeling, food safety standards, and general consumer protection laws, all of which are designed to foster awareness and communicate public preferences to the commercial proponents of GMOs in a way that will get their attention. (2011, p. 6)

In order to be effective, such labeling must be 'accurate, specific, and clearly expressed in understandable language, unbiased, and based on full disclosure of the relevant facts by the GMO proponents' (Prakash et al., 2011, p. 6).

The WHO study also recognized the need and responsibility for communicating risks to the public so that 'ethical components of food-safety decisions are clearly identified as early in the process as possible' and 'value-laden choices made by risk managers are made in an open, participatory process that respects the rights and roles of all stakeholders' (2005, p. 56).

\section{Conclusion}

In view of the most recent federal labeling statute in this area, the predominant query to consider may be the following: Do the current regulations, or lack of adequate and meaningful labeling, violate our responsibilities to others by not allowing them a choice as to whether they knowingly and willingly assume the risks of ingesting these genetically engineered substances? Efforts to quell the public outcry by preempting state and local community labeling initiatives would be better directed to incorporating these desires into the international policy arena.

The ethical implications are clear, followed by the expectation that the legal system should fill in the ethical gap as it has done in so many other areas and, at the very least, require meaningful labeling, pre-market approval and monitoring of GMOs in food products and ingredients. Fully informing the public and transparency in the regulatory process are the keys. Incorporating ethical tensions in the policy and regulation arena requires US policy makers to respond appropriately to the consumer demands that led to grassroots efforts and embrace rather than suppress these initiatives. Mandatory labeling that clearly and effectively discloses genetically engineered ingredients and processes would be the responsible next step.

\section{References}

Altieri, M.A. and Rosset, P. (1999) Ten reasons why biotechnology will not ensure food security, protect the environment and reduce poverty in the developing world. AgBioForum 2, 3. http://www.agbioforum.org/v2n34/v2n34a03altieri.htm

Atkinson, R.C. et al. (2003) Public sector collaboration for agricultural IP management. Science 301, 174-175. doi:10.1126/science.1085553

Batalion, N. (2009) 50 harmful effects of genetically modified food. Available at: http://www. raw-wisdom.com/50harmful (accessed 12 August 2017).

Begley, C. (2017) 'So close, yet so far': The United States follows the lead of the European Union in mandating GMO labeling. But did it go far enough? Fordham International Law Journal 40, 625-746. Available at: http://heinonline.org/HOL/Landing Page?handle $=$ hein.journals/frdint $40 \& \operatorname{div}=17$ (accessed 5 July 2018).

Brussel, L. (2003) Engineering a solution to market failure: a disclosure regime for genetically modified organisms. Cumberland Law Review 34, 427. Available at: http://heinonline.org/HOL/ LandingPage?handle=hein.journals/cumlr34\& div $=25$ (accessed 5 July 2018).

Center for Food Safety (n.d.) State bills. Available at: http://www.centerforfoodsafety.org/search/ state-bills (accessed 23 July 2017).

Center for Food Safety (2017) U.S. polls on GE food labeling. Available at: http://www. centerforfoodsafety.org/issues/976/gefoodlabeling/us-polls-on-ge-food-labeling\# (accessed 21 July 2017).

Connecticut General Statutes (2013) An Act Concerning Genetically-Engineered Food (Public Act No. 13-183). Available at: https://www.cga. ct.gov/2013/ACT/pa/pdf/2013PA-00183-R00HB06527-PA.pdf (accessed 23 July 2017).

Consumer Reports (2014) Where GMOs hide in your food. October. Available at: http://www. consumerreports.org/cro/2014/10/where-gmoshide-in-your-food/index.htm (accessed 21 July 2017).

Convention on Biological Diversity (2017) Genetic use restriction technologies (GURTs). Available 
at: https://www.cbd.int/agro/gurts.shtml (accessed 21 July 2017).

FAO (2001a) Ethical issues in food and agriculture. Available at: http://www.fao.org/DOCREP/ 003/X9601E/X9601E00.HTM (accessed 1 December 2017).

FAO (2001b) Genetically modified organisms, consumers, food safety and the environment. Availableat:http://www.fao.org/3/a.x9602e.pdf. (accessed 1 December 2017).

FAO (2005) Report of the panel of eminent experts on ethics in food and agriculture, Third session. Available at: http://www.fao.org/docrep/010/a0697e/ a0697e00.html (accessed 1 December 2017).

FAO (2007a) Panel of eminent experts on food and agriculture. Available at: http://www.fao.org/unfao/ govbodies/gsb-subject-matter/statutorybodies-details/en/c/432/?no_cache=1 (accessed 22 July 2017).

FAO (2007b) Report of the panel of eminent experts on ethics in food and agriculture, Fourth session. Available at: http://www.fao.org/docrep/014/ i2043e/i2043e.pdf (accessed 1 December 2017).

FDA (2015) Guidance for industry: voluntary labeling indicating whether foods have or have not been derived from genetically engineered plants. Available at: https://www.fda.gov/Food/GuidanceReg ulation/GuidanceDocumentsRegulatoryInforma tion/ucm059098.htm (accessed 21 July 2017).

FDA (2016) Food irradiation: What you need to know, 28 June. Available at: https://www.fda.gov/ food/resourcesforyou/consumers/ucm261680.htm (accessed 27 July 2017).

Gaskell, G., Bauer, M.W., Durant, J. and Allum, N.C. (1999) Worlds apart? The reception of genetically modified foods in Europe and the U.S. Science 285, 384-387. doi:10.1126/science.285.5426.384

GMA (2017) Grocery Manufacturers Association position on GMOs. Available at: http://www. gmaonline.org/file-manager/GMA\%20Position\% 20on\%20GMOs.pdf (accessed 21 July 2017).

Halloran, J. and Hansen, M. (1999) Why we need labeling of genetically engineered food. Synthesis/ Regeneration 18. Available at: http://www.greens. org/s-r/18/18-07.html (accessed 27 July 2017).

Hoffman, D.E. and Sung, F. (2005) Future public policy and ethical issues facing the agricultural and microbial genomics sectors of the biotechnology industry. Biotechnology Law Report 24, 10-28. doi:10.1089/blr.2005.24.10

Justlabelit (n.d.) GMO labeling in Congress. Available at: http://www.justlabelit.org/dark-act/ (accessed 23 July 2017).

Keane, S. (2006) Can a consumer's right to know survive the WTO? The case of food labeling. Transnational Law and Contemporary Problems 16, 291.
Kolehmainen, S. (2001) Precaution before profits: An overview of issues in genetically engineered food and crops. Virginia Environmental Law Journal20, 267-294. Available at: http://www.jstor.org/ stable/24785929 (accessed 5 July 2018).

Maine Legislature (2013) Maine revised statutes, title 22, § 2591. Available at: http://legislature. maine.gov/legis/statutes/22/title22sec2591.html (accessed 23 July 2017).

McCann, N. (2017) Now is our chance to get USDA to label GMOs on the package, 13 July. Available at:http://www.centerforfoodsafety.org/blog/5016/ now-is-our-chance-to-get-usda-to-label-gmoson-the-package\# (accessed 23 July 2017).

Melman Group (2015) Voters want GMO food labels printed on packaging. Available at: http:// 4bgr3aepis44c9bxt1ulxsyq.wpengine.netdnacdn.com/wp-content/uploads/2015/12/ 15memn20-JLI-d6.pdf (accessed 23 July 2017).

Merkley, J. (2016) Press Release, Merkley, Leahy, Tester, Feinstein introduce GMO food labeling legislation, 2 March. Available at: https://www. merkley.senate.gov/news/press-releases/merkleyleahy-tester-feinstein-introduce-gmo-food-labelinglegislation (accessed 23 July 2017).

Nat, H. (2016) Will consumers be in the 'dark' about labels on genetically engineered and modified foods? Journal of Food Law \& Policy 12, 199-213. Available at: http://heinonline.org/HOL/Landing Page?handle=hein. journals/jfool12\&div=13 (accessed 5 July 2018).

National Academies of Sciences, Engineering, and Medicine (NAS) (2016) Genetically Engineered Crops: Experiences and Prospects. NAS, Washington, DC. doi:10.17226/23395

Nauheim, D.A. (2009) Food labeling and the consumer right to know: Give the people what they want. Liberty University Law Review 4, 97-133. Available at: http://heinonline.org/HOL/Landing Page?handle=hein.journals/lunlr4\&div=5 (accessed 5 July 2018).

Nestle, M. (1996) Allergies to transgenic foods: Questions of policy. New England Journal of Medicine 334,726-728.doi:10.1056/NEJM199603143341111

Nordlee, J.A. et al. (1996) Identification of a Brazil nut allergen in transgenic soybeans. New England Journal of Medicine 334, 688-692. doi:10.1056/ NEJM199603143341103

PIPRA (n.d.) Public intellectual property resource for agriculture. Available at: http://www.pipra.org (accessed 28 July 2017).

Podger, G. (2004) European food safety authority will focus on science. The European Institute $\mathrm{V}(1)$. Available at: http://www.europeaninstitute. org/index.php/ei-blog/32-european-affairs/winter2004/309-european-food-safety-authoritywill-focus-on-science (accessed 28 July 2017). 
Prakash, D., Verma, S., Bhatia, R. and Tiwary, B.N. (2011) Risks and precautions of genetically modified organisms. ISRN Ecology 2011, 369573. doi: $10.5402 / 2011 / 369573$

Strauss, D.M. (1987) Reaffirming the Delaney Anticancer Clause: The legal and policy implications of an administratively created de minimis exception. Food Drug Cosmetic Law Journal 42, 393-428. Available at: http://heinonline.org/ HOL/LandingPage?handle=hein.journals/ foodlj42\&div=32 (accessed 5 July 2018).

Strauss, D.M. (2006) The international regulation of genetically modified organisms: Importing caution into the U.S. food supply. Food and Drug Law Journal 61, 167-168. Available at: http://heinon line.org/HOL/LandingPage?handle=hein.jour nals/foodlj61\&div=17 (accessed 5 July 2018).

Strauss, D.M. (2007) Defying nature: The ethical implications of genetically modified plants. Journal of Food Law \& Policy 3, 1-37. Available at: http://heinonline.org/HOL/LandingPage?handle= hein.journals/jfool3\&div=5 (accessed 5 July 2018).

Strauss, D.M. (2009) The application of TRIPS to GMOs: International intellectual property rights and biotechnology. Stanford Journal of International Law 45, 287-320. Available at: https://ssrn. com/abstract=1523514 (accessed 5 July 2018).

Strauss, D.M. (2011) An analysis of the FDA Food Safety Modernization Act: Protection for consumers and boon for business. Food and Drug Law Journal 66, 353-376. Available at: https://ssrn. com/abstract=1925008 (accessed 5 July 2018).

Strauss, D.M. (2012a) Liability for genetically modified food: Are GMOs a tort waiting to happen? The SciTech Lawyer 9, 8-13. Available at: https:// ssrn.com/abstract=2162255 (accessed 5 July 2018).

Strauss, D.M. (2012b) The role of courts, agencies, and Congress in GMOs: A multilateral approach to ensuring the safety of the food supply. Idaho Law Review 48, 267-319. Available at: http:// heinonline.org/HOL/LandingPage?handle=hein. journals/idlr48\&div=14 (accessed 5 July 2018).

Teitel, M. and Wilson, K. (1999) What You Need to Know to Protect Yourself, Your Family, and Your Planet. Park Street Press, Rochester, Vermont.

Tokar, B. (1999) Resisting biotechnology and the commodification of life. Synthesis/Regeneration 18. Available at: http://www.greens.org/s-r/18/ 18-01.html (accessed 26 July 2017).
United States (2012) Irradiation in the production, processing, and handling of food, Final Rule. Federal Register 77, 71316-71321. Available at: https://www.federalregister.gov/documents/ 2012/11/30/2012-28968/irradiation-in-theproduction-processing-and-handling-of-food (accessed 1 December 2017).

United States (2016) National bioengineered food disclosure standard, amending the Agricultural Marketing Act of 1946, Public Law 114-216 (7 U.S.C. 1621 et seq.) (2012). Available at: https:// www.congress.gov/114/plaws/publ216/ PLAW-114publ216.pdf (accessed 22 July 2017).

USDA (n.d.a) GMO disclosure and labeling. Available at: https://www.ams.usda.gov/rulesregulations/gmo (accessed 9 December 2017).

USDA (n.d.b) Proposed rules questions under consideration. Available at: https://www.ams.usda. gov/rules-regulations/gmo-questions (accessed 9 December 2017).

USDA (2017a) Adoption of genetically engineered crops in the U.S., 12 July. Available at: https:// www.ers.usda.gov/data-products/adoptionof-genetically-engineered-crops-in-the-us/ (accessed 21 July 2017).

USDA (2017b) Study of electronic or digital disclosure, 6 September. Available at: https://www. ams.usda.gov/reports/study-electronic-ordigital-disclosure; https://www.ams.usda.gov/ sites/default/files/media/USDADeloitteStudy ofElectronicorDigitalDisclosure20170801.pdf (accessed 9 December 2017).

Vermont Attorney General's Office (2016) Press Release, Attorney General will not enforce GE food labeling law, will advocate for clear on-package labels, 2 August. Available at: http://ago.vermont. gov/focus/news/attorney-general-will-not-enforce-gefood-labeling-law-will-advocate-for-clear-onpackage-labels.php (accessed 23 July 2017).

Vermont General Assembly (2014) H.112 (Act 120): An act relating to the labeling of food produced with genetic engineering. Available at: http:// www.leg.state.vt.us/docs/2014/Acts/ACT120. pdf (accessed 1 December 2017).

World Health Organization (WHO) (2005) Modern food biotechnology, human health and development: An evidence-based study. Available at: http://www.who.int/foodsafety/publications/ biotech/biotech_en.pdf (accessed 24 July 2017). 